\title{
Effect of Bone Marrow Versus Adipose Tissue Derived Mesenchymal Stem Cells on the Pancreas of Streptozotocin-Induced Diabetes Mellitus Type I in Adult Male Rats (Histological Study)
}

\section{Original Article}

Abeer Ibraheem Omar and Alshaymaa Gamal Aboulkhair

Department of Histology, Faculty of Medicine, Cairo University, Cairo, Egypt

\begin{abstract}
Background: Diabetes Mellitus (D.M.) is a major health problem affecting more than 200 million worldwide. The ideal treatment for autoimmune type I diabetes is regeneration of endogenous $\beta$-cells which could be achieved by mesenchymal stem cells transplantation.

Aim of the work: This work aimed to compare the effect of intravenous bone marrow derived mesenchymal stem cells (BMSCs) and adipose tissue derived mesenchymal stem cells (AMSCs) on Streptozotocin (STZ)-induced type I diabetes in albino rats. Material and Methods: Fifty albino male rats were divided into 4 groups; control, diabetic, BMSCs treated and AMSCs treated. Treated groups were intravenously given $1 \mathrm{ml}$ PKH26 labeled allogenic BMSCs or AMSCs suspended in phosphate buffered saline, respectively. Animals of all groups were sacrificed 2 weeks after stem cells administration. Sections from control and treated groups were examined by fluorescence microscope. Sections from all groups were immunohistochemically stained to detect insulin and proliferating cell nuclear antigen (PCNA). Mean area percent of insulin and number of PCNA positive reactions were measured and statistically analyzed.

Results: Diabetic rats showed cell death and congested blood vessels in both exocrine and endocrine pancreas. Treated groups revealed homing of stem cells in pancreas after their transplantation. Moreover, nearly normal histological features were seen in AMSCs treated group. Studying the treated groups immunohistochemically, revealed increase in insulin and PCNA positive reactions when compared to diabetic group with more increase in AMSCs treated group than BMSCs treated group. Conclusion: Intravenous AMSCs could be more effective than BMSCs in treatment of STZ-induced type I diabetes.
\end{abstract}

Key Words: Diabetes type I, BMSCs, AMSCs, insulin, PCNA.

Received: 22 December 2016, Accepted: 30 April 2017

Corresponding Author: Abeer Ibraheem Omar, Tel.: 00201002596677, E-mail: kaboree2002@gmail.com

ISSN: $1110-0559$, March 2017, Vol. 40, No. 1

\section{INTRODUCTION}

Diabetes mellitus is a major health problem that affects more than 200 million all over the world ${ }^{[1]}$. It is a major cause of morbidity and mortality due to its micro and macrovascular complications ${ }^{[2]}$.

It is of two types (type I and type II). Type I diabetes represents $10 \%$ of the diabetic cases with increased incidence in the developed countries ${ }^{[3]}$. It is an autoimmune destruction of the pancreatic insulin producing $\beta$-cells that resulted from abnormal activation of T-cells ${ }^{[4]}$. A range of $60 \%-80 \%$ of the $\beta$-cells would be destroyed at the time of diagnosis of diabetes type ${ }^{[5]}$.

Treatment of type I diabetes includes control of food intake and insulin therapy. These methods can not simulate the natural secretion of insulin in the body leading to life threatening complications as severe hypoglycemic or hyperglycemic attacks ${ }^{[6]}$. Another way of treatment depended on transplantation of the whole pancreas or the pancreatic islets cells. However, they were limited by the shortness of donors and the rejection complications ${ }^{7]}$. So, the ideal therapeutic tool would be regeneration of the endogenous $\beta$-cells ${ }^{[8]}$.

Mesenchymal stem cells are multipotent stem cells that can be isolated from bone marrow, adipose tissue, umbilical cord and many other tissues ${ }^{[9]}$. They could be used in regenerative medicine as they have the ability to renew themselves, differentiate into a wide range of cells and have high potentiality to expand in culture ${ }^{[10]}$. In addition, they have angiogenic, anti-apoptpotic, antiinflammatory and immunomodulatory effects ${ }^{[11]}$.

BMSCs and AMSCs are two types of different origins for adult mesenchymal stem cells ${ }^{[12]}$. Recovery of the 
pancreatic $\beta$-cells and controlling the blood glucose level in cases of diabetes could be achieved by transplantation of $\mathrm{BMSCs}^{[13]}$ as well as AMSCs ${ }^{[14]}$.

This study aimed to compare between the effect of intravenous injection of allogenic rat BMSCs and AMSCs on the pancreas of STZ-induced type I diabetes mellitus in adult male albino rats.

\section{MATERIAL AND METHODS}

\section{I-Animals:}

Fifty adult male albino rats (180-200g) were housed in Kasr Al-Aini animal house, Faculty of Medicine, Cairo University. The animals were chosen after measuring the random blood sugar (RBS) level by glucometer and those rats with RBS less than $200 \mathrm{mg} / \mathrm{dl}$ were chosen. The rats were treated in accordance with guidelines approved by the Animal Use Committee of Cairo University. The rats were provided with ordinary rat chow, bred and housed in wire mesh cages at temperature $\left(24 \pm 1^{\circ} \mathrm{c}\right)$, with normal light-dark cycle. All animals were kept under the same environmental conditions and had free access to water and food.

\section{II-Chemical used:}

Streptozotocin (STZ), an antibiotic purchased from Sigma Company (St. Louis, MO, USA). It was dissolved in sodium citrate buffer (0.1 mM, PH 4.4) immediately before its use.

\section{III-Stem cells:}

Allogenic PKH26 labeled rat BMSCs and AMSCs were purchased from stem cell research unit at the Biochemistry Department, Faculty of Medicine, Cairo University.

\section{Preparation of the stem cells:}

\section{Isolation of AMSCs:}

Subcutaneous white adipose tissue was excised from the rat's inguinal pad of fat under complete aseptic conditions. The adipose tissue was resected and placed into a labelled sterile tube containing $15 \mathrm{ml}$ of a phosphate buffered solution (PBS) (Sigma, USA, P5493). Enzymatic digestion was performed using $0.075 \%$ collagenase II (Serva Electrophoresis GmbH, Mannheim) in Hank's Balanced Salt Solution for 60 minutes at $37^{\circ} \mathrm{C}$ with gentle shaking. Digested tissue was filtered and centrifuged and erythrocytes were removed by treatment with erythrocyte lysis buffer. The cells were transferred to tissue culture flasks with Dulbecco Modified Eagle Medium (DMEM) (Sigma, USA, D5796) supplemented with $10 \%$ fetal bovine serum (FBS) (Sigma, USA, F6178). After an attachment period of 24 hours, non-adherent cells were removed by a PBS wash. Attached cells were cultured in DMEM media supplemented with $10 \%$ FBS, $1 \%$ penicillin-streptomycin (Sigma, USA, P4333), and $1.25 \mathrm{mg} / \mathrm{L}$ amphotericin B (Gibco/ BRL) and incubated at $37^{\circ} \mathrm{C}$ in $5 \%$ humidified $\mathrm{CO}_{2}$ for 14 days. The media were changed every 3-4 days. At 80- 90\% confluence, cultures were washed twice with PBS and the cells were trypsinized with $0.25 \%$ trypsin (Sigma, USA, T1426) in $1 \mathrm{ml}$ Ethylene Diamine Tetra Acetate (EDTA) (Sigma, USA, E6758) for $5 \mathrm{~min}$ at $37^{\circ} \mathrm{C}$. After centrifugation (at $2400 \mathrm{rpm}$ for 20 minutes), cell pellets were re-suspended with serum- supplemented medium and incubated in $50 \mathrm{~cm}^{2}$ culture flask (Falcon). The resulting cultures were referred to as first-passage cultures which then expanded in vitro until passage four ${ }^{[15]}$.

\section{Morphological identification of AMSCs:}

AMSCs in culture were characterized by their adhesiveness, fusiform shape and by detection of CD29, one of the surface markers of rat AMSCs, by Flow cytometry. AMSCs differentiation into chondrocytes and osteocytes was confirmed ${ }^{[16]}$.

\section{Isolation of BMSCs:}

Bone marrow mesenchymal stem cells were obtained from femurs and tibiae of the rats by aspiration. They were isolated by flushing the bone marrow cavity with DMEM supplemented with $10 \%$ FBS. The cells were layered over Ficoll-Hypaque (Sigma, USA, F8016) in a ratio of $2: 1$ in sterile conical tubes and centrifuged ${ }^{[17]}$. The opaque layer containing the mononuclear cells was aspirated and suspended in culture media as in AMSCs.

\section{Morphological identification of BMSCs:}

BMSCs in culture were characterized by their adhesiveness, fusiform shape and by detection of CD29 and CD45, surface markers of rat BMSCs, by Flow cytometry ${ }^{[18]}$.

Cell viability analysis and labeling of AMSCs and BMSCS with PKH26 dye:

Cell viability was detected by adding $1: 1$ ratio of cell suspension and $0.4 \%$ trypan blue stain, and examined under the phase contrast microscope. Viable cells appeared shiny without staining ${ }^{[19]}$.

Culture cells were labelled with fluorescent cell tracker PKH26 (Sigma, USA, MINI26) according to manufacturer's instructions ${ }^{[20]}$. 


\section{IV-Experimental design:}

\section{The animals were divided into 4 groups:}

Group I (control group, $n_{.}=20$ rats):

\section{They were subdivided into four subgroups.}

Subgroup IA: 5 rats received no treatment.

Subgroup IB: 5 animals were given single intraperitoneal injection of $1 \mathrm{ml}$ of sodium citrate buffer (0.1 mM, PH 4.4) after being starved for 12 hours.

Subgroup IC: 5 animals were prepared as in Subgroup IB then 3 days later they received $1 \mathrm{ml}$ of PKH26 labeled allogenic BMSCs suspension in PBS $\left(1 \times 10^{6}\right.$ cells $\left./ \mathrm{ml}\right)$ through the tail vein.

Subgroup ID: 5 animals were prepared as in Subgroup IB then 3 days later they received $1 \mathrm{ml}$ of PKH26 labeled allogenic AMSCs suspension in PBS $\left(1 \times 10^{6}\right.$ cells $\left./ \mathrm{ml}\right)$ through the tail vein.

Group II (Diabetic untreated group, $n .=10$ rats):

Diabetes type I was induced in these animals using STZ. Three days later, RBS level was measured by glucometer. Rats with blood glucose levels above $200 \mathrm{mg} / \mathrm{dl}$ were considered diabetic ${ }^{[21]}$. Then the animals were subdivided into:

Subgroup IIA (5 rats): received nothing following STZ.

Subgroup IIB (5 rats): received single dose of $1 \mathrm{ml}$ of PBS through the tail vein.

\section{Group III (BMSCs treated group, $n_{.}=10$ rats):}

Three days after induction of type I diabetes as in group II, RBS level of the rats of this group was measured by glucometer to confirm diabetes (more than $200 \mathrm{mg} / \mathrm{dl}$ ). The rats received $1 \mathrm{ml}$ of PKH26 labeled allogenic BMSCs suspension in PBS $\left(1 \times 10^{6}\right.$ cells $\left./ \mathrm{ml}\right)$ through the tail $\operatorname{vein}^{[22]}$.

\section{Group IV (AMSCs treated group, $n .=10$ rats):}

Three days after induction of type I diabetes as in group II, RBS level of the rats of this group was measured by glucometer to confirm diabetes (more than $200 \mathrm{mg} / \mathrm{dl}$ ). The rats received $1 \mathrm{ml}$ of PKH26 labeled allogenic AMSCs suspension in PBS $\left(1 \times 10^{6}\right.$ cells $\left./ \mathrm{ml}\right)$ through the tail vein $^{[23]}$.

\section{V- Experimental procedure:}

\section{Induction of diabetes:}

Animals were starved for $12 \mathrm{~h}$ then received a single intraperitoneal injection of $60 \mathrm{mg} / \mathrm{kg}$ of STZ dissolved in 1 $\mathrm{ml}$ sodium citrate buffer immediately after its preparation in Biochemistry Department, Faculty of Medicine, Cairo University [24]. The aim of this procedure is to induce type I diabetes Mellitus ${ }^{[25]}$.

Two weeks after stem cells transplantation, the RBS level was measured for all animals then the animals of all groups were sacrificed with an over dose of intravenous Phenobarbital $(100 \mathrm{mg} / \mathrm{kg})$ in Histology Department, Faculty of Medicine, Cairo University. The pancreas of all animals were dissected, fixed in Bouin solution and processed to obtain Paraffin blocks. Paraffin sections 5 micrometers thick were cut. Unstained sections from subgroups IC \& ID together with unstained sections from groups III and IV were examined by fluorescent microscope. Sections of all groups were stained by:

- Hematoxylin and Eosin stain ${ }^{[26]}$.

- Immunohistochemical staining ${ }^{[27]}$ for:

1. Insulin antibody: It is a guinea pig polyclonal antibody (Lab Vision Corporation Laboratories, catalogue number PA1 -36022).

2. PCNA (Proliferating Cell Nuclear Antigen) antibody: It is a rabbit polyclonal antibody (Lab Vision Corporation Laboratories, catalogue number PA5 -27214).

Immunostaining required pretreatment, this was done by boiling for 10 minutes in $10 \mathrm{Mm}$ citrate buffer (cat no AP 9003) pH 6 for antigen retrieval and leaving the sections to cool in room temperature for 20 minutes. Then, the sections were incubated for one hour with the primary antibodies (this step was omitted in negative control sections). Immunostaining was completed by the use of Ultravision detection system (cat no TP 015- HD). Counterstaining was done using Mayer's hematoxylin (cat no TA- 060- MH). Primary antibodies, citrate buffer, Ultravision detection system and Mayer's hematoxylin were purchased from Lab Vision Corporation Laboratories USA.

Insulin immunopositive reaction appears as brown cytoplasmic deposits while that of PCNA appears as brown nuclear deposits. 
VI- Morphometric study: It included measuring of:

- Mean area percent of insulin immuno-expression in islets of Langerhans in insulin immunostained sections.

- Mean number of PCNA positive cells in islets of Langerhans in PCNA immunostained sections.

All measurements were done in 10 non overlapping fields for each animal of each subgroup. Image analysis was done using Leica Qwin 500 LTD software image analysis computer system (Cambridge, England) in Histology department, Faculty of Medicine, Cairo University.

\section{VII-Statistical analysis:}

The morphometric measurements were expressed as mean \pm standard deviation (SD) and were analyzed statistically using the software "Statistics for windows SPSS" version 16. This was done using one-way analysis of variance ANOVA followed by "tuckey" post hoc test. Results were considered significant when $P$ value was $<0.05^{[28]}$.

\section{RESULTS}

\section{General Observation:}

No deaths or abnormal behavior were observed in all rats except for the presence of excessive urination in the diabetic group, two days after STZ injection. The biochemical, histological and immunohistochemical results of all subgroups of control group (group I) were similar. The diabetic rats in group II (subgroup IIA \& IIB) also showed the same biochemical, histological and immunohistochemical results. So, they were referred to by control group (group I) and diabetic group (group II), respectively.

\section{I-Random Blood Sugar (RBS) level (Table 1):}

The mean values of random blood sugar level of diabetic rats in group II were significantly increased when compared to control rats of group I. The mean values of random blood sugar level of the treated rats (groups III \& IV) revealed significant decrease two weeks after stem cell transplantation when compared with diabetic rats and it showed significant decrease in group IV than in group III. However, the RBS level in group IV had not returned to the normal level and it showed a significant increase when compared with the control group.

\section{II-Histological results:}

\section{Fluorescent Microscope Results:}

Sections of the control subgroups IC and ID showed absence of PKH26 labeled stem cells (Fig. 1a). Sections of the BMSCs treated group (III) (Fig. 1b) and AMSCs treated group (IV) (Fig. 1c) showed the presence of PKH26 labeled stem cells in islets of Langerhans and in some pancreatic acini.

\section{Hematoxylin and Eosin stained pancreatic sections:}

Control group revealed normal structure of the endocrine and exocrine parts of the pancreas (Fig. 2a). The diabetic group revealed vacuolations of most of islet cells, the nuclei were small condensed and darkly stained. Congested capillaries were noticed. The exocrine pancreas showed congested blood vessels and darkly stained condensed nuclei of some acinar cells (Figs. $2 \mathrm{~b}$ and c). Few islets cells of the sections of group III showed vacuolations and small darkly stained condensed nuclei while very few acinar cells showed darkly condensed nuclei (Fig. 2d). Sections of group IV showed a pancreatic structure (endocrine and exocrine parts) nearly similar to that of the control group except for the presence of very few small darkly stained condensed nuclei in the islets of Langerhans (Fig. 2e).

\section{Anti-insulin stained pancreatic sections:}

Sections of control group revealed dense cytoplasmic immunoreactivity in most of the cells of the pancreatic islets of Langerhans (Fig. 3a). Sections of diabetic group revealed markedly diminished immunoreactivity detected mainly in the peripheral part of the islets that showed many vacuolated areas (Fig. 3b). Sections of group III revealed that many cells of the islets of Langerhans showed positive immunoreactivity (Fig. 3c). Sections of group IV revealed that most of the islets cells were positive for insulin immunostaining (Fig. 3d).

\section{Anti-PCNA stained pancreatic sections:}

Sections of control group revealed no immunoreactivity (Fig. 4a) while sections of diabetic group revealed nuclear immunoreactivity that was detected in very few islet cells (Fig. 4b). Sections of group III revealed nuclear immunoreactivity in more islet cells and very few acinar cells (Fig. 4c). Group IV revealed abundant nuclear immunoreactivity that was detected in most islet cells, some acinar cells and endothelial cells lining the blood vessel present in-between the acini. Some immunoreactive nuclei were observed near the blood vessel closely related to the islets (Fig. 4d).

\section{III-Morphometric results:}

\section{I- Mean area percent of insulin immunopositive cells (Table 2):}

The mean area percent of insulin immunopositive cells of diabetic rats in group II were significantly 
decreased when compared to control rats. Treated rats (groups III \& IV) revealed a significant increase in the mean area percent of insulin immunopositivy two weeks after stem cell transplantation when compared to diabetic rats. Group IV demonstrated a significant increase versus group III but the insulin immunoexpression in it had not returned to the normal level and its mean area percent showed a significant decrease when compared with that of the control group.

\section{II-Mean number of PCNA immunopositive cells (Table 3):}

PCNA immunopositive cells were not detected in control rats. In treated rats of groups III \& IV, it revealed significant increase two weeks after stem cell transplantation versus diabetic rats. It also showed significant increase in group IV than group III.

Table 1: The mean values $( \pm \mathrm{SD})$ of random blood sugar level, expressed as $\mathrm{mg} / \mathrm{dl}$, of control and experimental subgroups at the end of the experiment.

\begin{tabular}{lcc} 
Group & & Mean $(\mathrm{mg} / \mathrm{dl}) \pm \mathrm{SD}$ \\
\hline I & A & $90.2 \pm 3.4$ \\
& B & $89.9 \pm 4.5$ \\
& C & $91 \pm 3.6$ \\
& D & $87.9 \pm 4.9$ \\
II & A & $376.8 \pm 8.8^{*}$ \\
& B & $373.3 \pm 8.7^{*}$ \\
III & & $320.3 \pm 10.2^{*} \square$ \\
IV & & $278.5 \pm 6.3^{*} \square \circ$ \\
\hline
\end{tabular}

$* P<0.05$ as compared to group I.

$\square P<0.05$ as compared to group II.

$\circ P<0.05$ as compared to group III.

Table 2: The mean values ( \pm SD) of area percent of insulin immunopositive cells in the control and experimental groups.

\begin{tabular}{lc} 
Group & Mean Area Percent \pm SD \\
\hline I & $12.6 \pm 1.2$ \\
II & $2.2 \pm 0.71^{*}$ \\
III & $7.2 \pm 0.72 * \square$ \\
IV & $9.2 \pm 1.1^{*} \square \circ$ \\
\hline
\end{tabular}

* $P<0.05$ as compared to group I.

$\square P<0.05$ as compared to group II.

$\circ P<0.05$ as compared to group III.
Table 3: The mean number $( \pm \mathrm{SD})$ of PCNA immunopositive cells in the experimental groups.

\begin{tabular}{lc} 
Group & Mean Number $\pm \mathrm{SD}$ \\
\hline II & $2.2 \pm 1.0$ \\
III & $5.8 \pm 0.78 \square$ \\
IV & $10.2 \pm 1.32 \square \circ$ \\
\hline
\end{tabular}

$\square \mathrm{P}<0.05$ as compared to group II.

$\circ \mathrm{P}<0.05$ as compared to group III
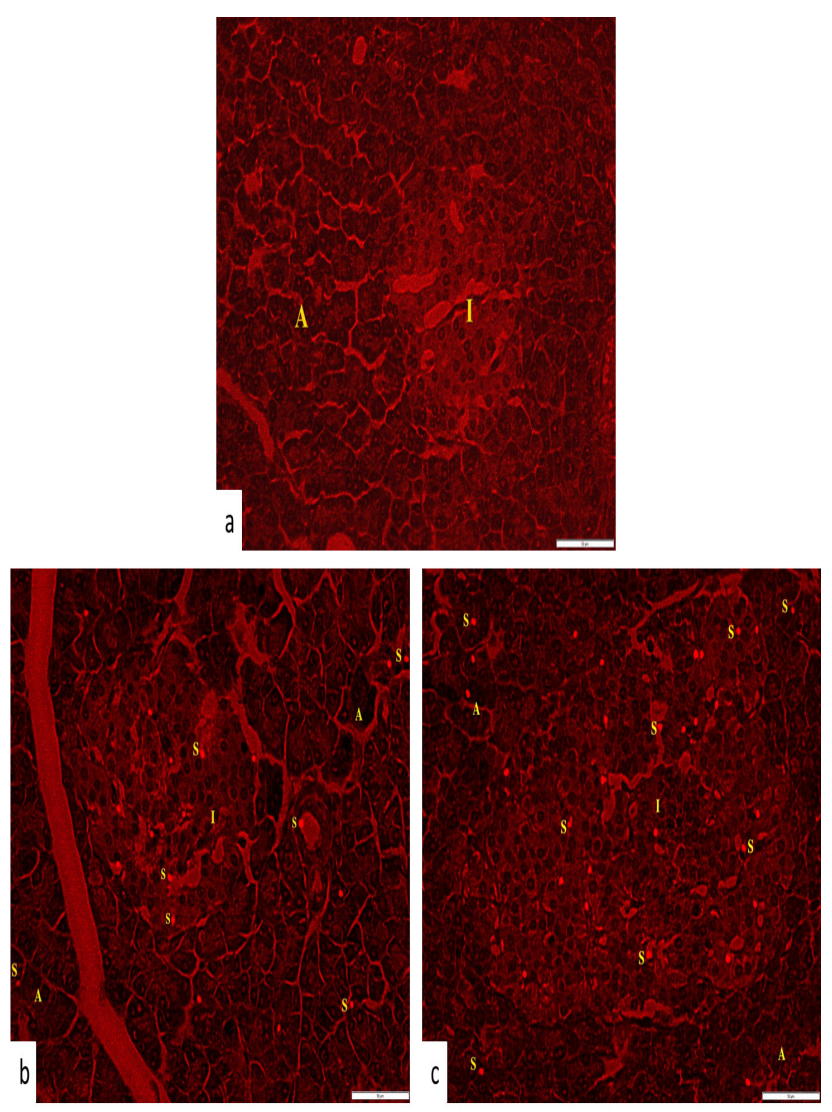

Fig. 1: Photomicrographs of sections in the pancreas of albino rats show one islet (I) surrounded by many pancreatic acini (A) with absent PKH26 labeled stem cells in the control subgroup IC (a). PKH26 labeled BMSCs (S) in group III (b) and PKH26 labeled AMSCs (S) in group IV (c) are seen in the islet (I) and some pancreatic acini (A).

(Fluorescent microscope image, x 200) 

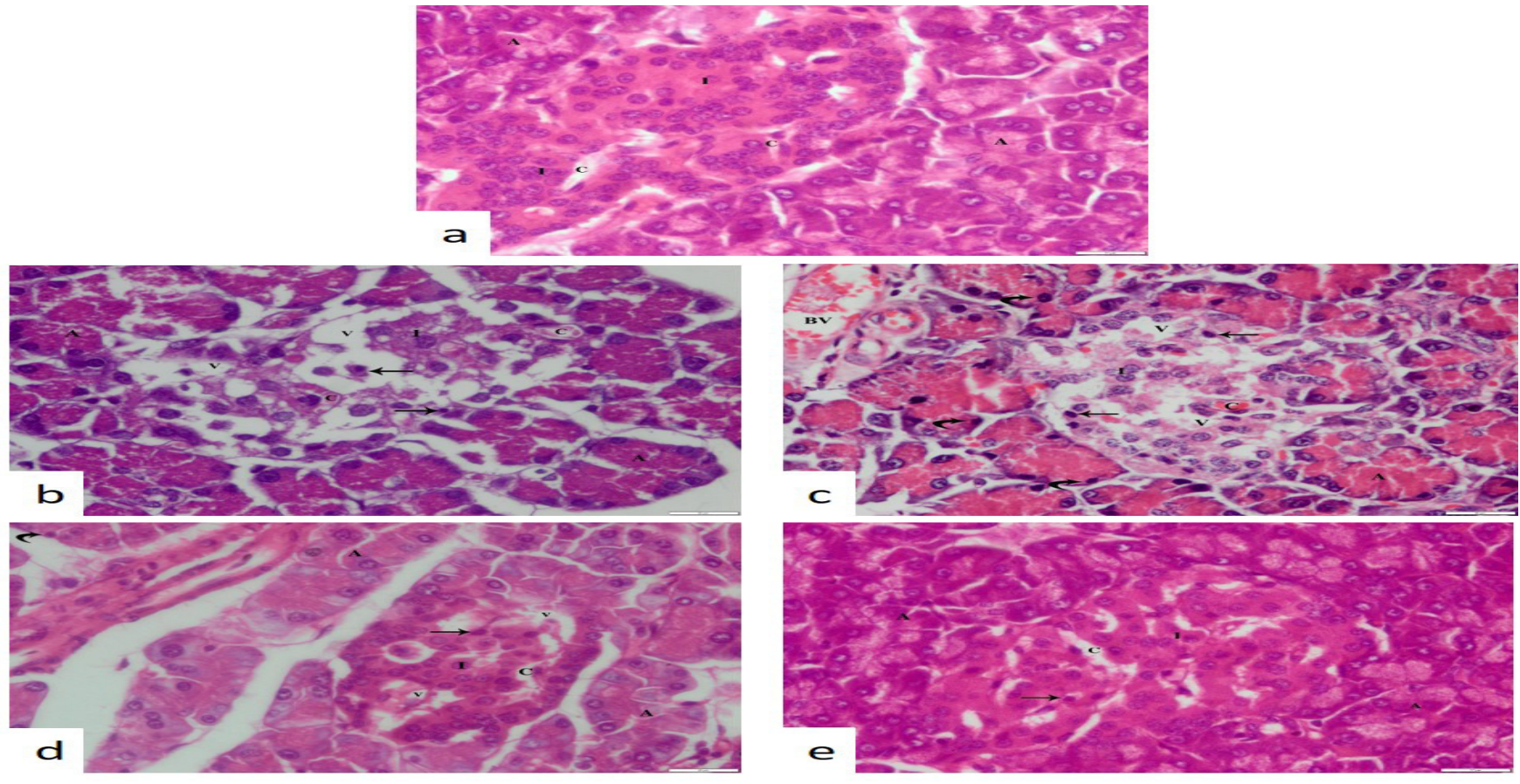

Fig. 2: Photomicrographs of sections in the pancreas of albino rats showing an islet (I) rich in capillaries (c) surrounded by many pancreatic acini (A) in group I (a). Group II shows an islet (I) with congested capillaries (c) surrounded by many pancreatic acini (A). Most of islet cells show vacuolations (V). Other cells show small darkly stained condensed nuclei (arrows) (b \& c). The exocrine part shows congested blood vessels (BV) \& darkly stained condensed nuclei of some acinar cells (curved arrows) (c). The islet (I) with normal appearance of blood capillary (C) shows few cells with vacuolations (v) and small darkly stained condensed nuclei (arrow). Very few cells of the acini (A) show darkly stained condensed nuclei (curved arrow) in group III (d). In group IV, very few islet (I) cells show small darkly stained condensed nuclei (arrow). The islet is surrounded by many apparently normal pancreatic acini (A). Note the apparently normal blood capillaries (C) within the islet (e)

$(\mathrm{H} \& \mathrm{E}, \mathrm{x} 400)$


Fig. 3: Photomicrographs of sections in the pancreatic acini (A) and islets (I) of albino rats showing dense cytoplasmic immunoreactivity (arrows) in most of islet cells in group I (a). Few cells with positive immunoreactivity are seen at the periphery of the islet of Langerhans (arrows). Many vacuolations can be seen (v) in group II (b). Dense cytoplasmic immunoreactivity (arrows) is detected in many islet cells in group III (c) and in most of islet cells in group IV (d).

(Anti-insulin Immunostaining x400) 

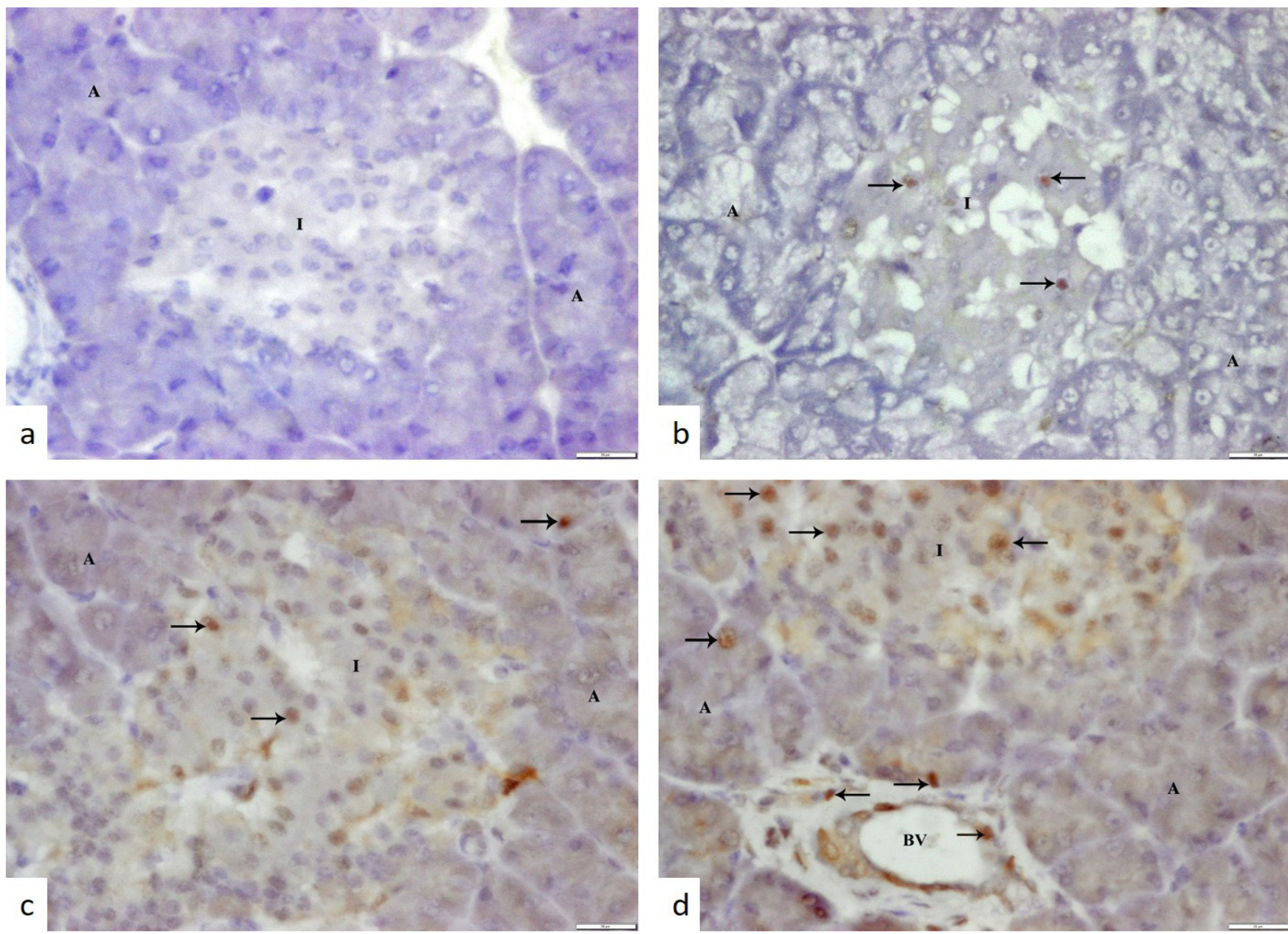

Fig. 4: Photomicrographs of sections in the pancreatic acini (A) and islets (I) of albino rats showing negative nuclear immunoreactivity in all islet cells in group I (a). Very few immunoreactive nuclei (arrows) are seen in islet cells in group II (b). Some islet cells and very few acinar cells show immunoreactive nuclei (arrows) in group III (c) while in group IV (d) the immunoreactivity is detected in most islet \& some acinar cells (arrows). It is also shown near the blood vessel (BV) closely related to the islet and in its lining endothelial cells (arrows) (d).

(Anti-PCNA Immunostaining x400)

\section{DISCUSSION}

In the current study, Three days following STZ administration, diabetes was induced as the blood sugar level of the rats was above $200 \mathrm{mg} / \mathrm{dl}^{[21]}$. The induced diabetes was similar to the T-cell-mediated autoimmune type I diabetes ${ }^{[25]}$. The islets of Langerhans showed congested blood capillaries and most of the cells had vacuolations in their cytoplasm revealing cellular necrosis. Some cells showed features of apoptosis; cells with small darkly stained condensed nuclei (pyknotic nuclei). These findings coincide with a recent research that reported the degeneration of $\beta$-cells of islets of Langerhans following STZ injection $^{[29]}$. These observations could explain the persistent elevation of the random blood sugar level and the significant decrease in the mean area percent of insulin positive reaction in the diabetic group versus the control group detected in the current study. These findings are similarly reported by a more recent study ${ }^{[21]}$ where the blood glucose level in the diabetic group was significantly higher when compared to the control group and insulin reactivity was markedly decreased in both immunohistochemical and immunofluorescence stained sections.

In this study, the exocrine pancreas was also affected following STZ administration in the diabetic rats. It showed congested blood vessels \& darkly stained condensed nuclei of some acinar cells (pyknosis). These findings are in line with those stated in recent studies ${ }^{[30,31]}$ where vacuolations and pyknotic nuclei of some acinar cells with dilatation, thickening and congestion of the blood vessels were detected. The mechanism of exocrine pancreas affection in diabetic rats was not clear. However, this affection could be assumed to occur due to either direct effect of STZ or secondary to the induced diabetes. 
Streptozotocin was reported in previous studies ${ }^{[30,32]}$ to increase the release of reactive oxygen species causing DNA damage and ATP depletion through activatation of poly ADP-ribose polymerase-1 (PARP-1); the DNA repair enzyme that lead to ATP dephosphorylation. Moreover, STZ released toxic amounts of nitric oxide that participated in DNA damage. These STZ effects could result in degeneration of islet $\beta$ cells \& pancreatic acinar cells.

It was also assumed that the exocrine pancreas affection might be due to diabetes itself. This suggestion was based on a more recent study ${ }^{[31]}$ which mentioned that diabetes resulted into oxidative stress and cellular damage due to disturbance in the oxidative/ anti-oxidative balance. This disturbance resulted from increased production of oxygen free radicals through autoxidation of glucose, peroxiadation of lipids and glycosylation of proteins occurred secondary to persistent hyperglycemia accompanying diabetes. In addition to, diminished anti-oxidant activities caused by diabetes. Further support to this assumption was the presence of insulin receptors on the pancreatic cells, especially the acinar cells that controlled the activities of the exocrine part of the pancreas. On top of the evidence of human exocrine pancreatic dysfunction in diabetes, especially type I where the pancreas might be atrophied with fatty infiltration. Furthermore, the dramatic fall in the exocrine pancreatic activity as a part of the acute effects of STZ-induced diabetes type I in experimental animals ${ }^{[33]}$.

Through interpretation of the results of the current study, it would be appropriate to assume that both BMSCs and AMSCs could ameliorate $\beta$-cells and acinar cells degeneration induced by STZ. The H\& E stained sections revealed apparently normal histological structure of the islets of Langerhans and pancreatic acini with minimal affection in the treated groups (III \&IV). These findings are similar to what was detected in previous studies ${ }^{[3,34]}$ where BMSCs transplantation group had nearly normal islets of Langerhans. In addition further support could be attained by a former study ${ }^{[14]}$ which reported that intravenous injection of AMSCs decreased the islets cells degeneration induced by STZ, lowered the fasting blood glucose and increased insulin secretion by $\beta$-cells when compared to the diabetic group. This could be enforced in the present work by the abundant positive insulin immunoreaction and the significant increase in its mean area percent in islets $\beta$-cells in the treated groups (III and IV) in comparison with the diabetic group (II). Additionally, there was significant decrease in the mean value of RBS level in these groups versus the diabetic group.

The preservation of the pancreatic islets of Langerhans by mesenchymal stem cells either of bone marrow or adipose tissue origin detected in the treated groups (III and IV) was suggested to occur through two theories. The first one was assumed to involve paracrine mechanisms by expressing trophic and immunomodulatory factors. These trophic factors such as growth factors, anti-apoptotic, immunomodulatory and angiogenic factors would be capable to regenerate the injured tissues even if the stem cells didn't home in them ${ }^{[35,36]}$. This assumption was supported in the present work by the increase in cellular proliferation of the pancreatic islets, acini and blood vessels detected by increased PCNA positive immunostaining and the significant increase in the mean number of PCNA positive nuclei in the stem cell treated groups (III and IV) than in the diabetic group. This supposition could occur through change in the tissue microenvironment which was considered the most important mechanism of action of the mesenchymal stem cells ${ }^{[37]}$. This change could explain the ability of human BMSCs to treat the autoimmune type of diabetes (type $\mathrm{I})^{[38]}$ most probably through the ability of BMSCs to stop anti $\beta$-cells specific T-cell proliferation in the pancreas. Furthermore they could protect the newly formed $\beta$-cells from being destroyed by T-cells through secretion of immunomodulatory factors ${ }^{[34]}$. Noteworthy is that the preserving effect of the paracrine mechanism of the mesenchymal stem cells was suggested to extend to involve not only the function of the $\beta$-cells but also the sensitivity of the tissues to insulin, especially the skeletal muscles. This occurred through increasing the phosphorylation of the insulin receptor substrate-1 and protein kinase $\mathrm{B}^{[39,40]}$.

The second theory of the pancreatic preservation by the mesenchymal stem cells might be through their differentiation into $\beta$-cells of islets of Langerhans. Some studies found that the stem cells survived and differentiated into $\beta$-cells with subsequent increase in the number and size of islets of Langerhans ${ }^{[21,41]}$. This theory was supported in the current study by homing of the PKH26 labeled BMSCs and AMSCs, two weeks after their intravenous injection, into the pancreas of the treated groups (III and IV), respectively. Such homing could be explained by expression of certain chemokines receptors (CXCR4) by BMSCs. The ligand of this receptor, stromal cell derived factor-1 (SDF-1), was expressed by several tissues and upregulated by injury or ischemia ${ }^{[42]}$. This theory was opposed in a previous study ${ }^{[43]}$ which reported that in the stem cells treated group, GFP (green florescent protein) and $\mathrm{Y}$ chromosome positive BMSCs were found only in blood, lymphatic and interstitial cells of the pancreas not in the islets cells.

The current study assumed that transplantation of AMSCs gave better results than transplantation of BMSCs in the treatment of diabetes type I. This 
assumption based on that RBS was significantly decreased in AMSCs treated group than in BMSCs treated group. In addition to the mean area percent of insulin positive immunoreaction, where it showed significant increase in AMSCs treated group (IV) than in BMSCs treated group (III). Further enforcement to this assumption was the significant increase in the mean number of PCNA positive immunoreaction in AMSCs treated group than in BMSCs treated group. This could be explained by the ability of AMSCs to secrete more trophic factors than BMSCs ${ }^{[44]}$. Furthermore, AMSCs were proved to have higher proliferative capacity and faster tendency to form colonies in vitro than BMSCs especially in short term cultures. However, in cultures more than 60 days, they lost their proliferative capacity which was retained by BMSCs. This could make AMSCs less tumorigenic than BMSCs where low but detectable telomerase activity was found ${ }^{[45]}$. Moreover, AMSCs were proved to be more powerful than BMSCs in inhibition of lymphocytic proliferation [46] and prevention of activation of CD4+ \& CD8+ T-cell and CD56+ natural killer (NK) cells ${ }^{[47]}$. This could make AMSCs more effective than BMSCs in treatment of diabetes, especially the T-cell-mediated autoimmune type I diabetes. In addition, AMSCs were known by their safety, efficacy, abundance and ease harvesting and obtaining from discarded adipose tissue during surgery without ethical debate $^{[48,49]}$.

Although AMSCs in the current study was better than BMSCs in improving induced diabetes type I, the mean area percent of insulin was significantly decreased than that of the control group. Such finding might explain the significant increase and non-return of RBS to normal level in group IV when compared to control group. The low insulin secretion detected in group IV might be explained by the small number of stem cells reaching the pancreas after their transplantation. Hence, the attraction of the stem cells to the site of injury mediated by stem cells' chemokines and their injured tissue ligands might be not enough to attract sufficient amount of stem cells to the site of lesion to restore normal conditions ${ }^{[50]}$.

\section{CONCLUSION}

As STZ-induced diabetes detected in the present study was considered as a model for type I diabetes, it would be appropriate to conclude that intravenous administration of mesenchymal stem cells (BMSCs \& AMSCs) could be used in treatment of diabetes type I. The use of AMSCs could be more effective than BMSCs due to their better preservation of the pancreatic tissues. Such superior preservation was based on more histological conservation of the pancreas, lower RBS level and more insulin secretion in AMSCs treated group than BMSCs treated group.

\section{CONFLICT OF INTEREST}

There are no conflicts of interest.

\section{REFERENCES}

1. Shaw J, Sicree R and Zimmet P: Global estimates of prevalence of diabetes for 2010 and 2030 in Diabetes Res Clin Pr (2010) 87: 414-.

2. Joshua I G, Zhang Q, Falcone JC, Bratcher AP, Rodriguez WE and Tyagi SC: Mechanisms of endothelial dysfunction with development of type 1 diabetes mellitus: role of insulin and C-peptide in J Cell Biochem (2005) 96: 11491156-.

3. Ezquer $\mathrm{F}$, Ezquer $\mathrm{M}$, Simon $\mathrm{V}$ and Conget $\mathrm{P}$ : The antidiabetic effect of MSCs is not impaired by insulin prophylaxis and is not improved by a second dose of cells in PLoS ONE (2011) $6(1): 1-9$.

4. Atkinson $\mathrm{M}$ and Eisenbarth G: Type 1 diabetes: new perspectives on disease pathogenesis and treatment in Lancet (2001) 358: 221229-.

5. Notkins A and Lernmark A: Autoimmune type 1 diabetes: resolved and unresolved issues in $\mathrm{J}$ Clin Invest (2001) 108: 1247 -1252.

6. Balamurugan $\mathrm{AN}$ and Giannoukakis $\mathrm{N}$ : Prospective and challenges of islet transplantation for the therapy of autoimmune diabetes in Pancreas (2006) 32(3): 231- 243

7. Farge D: Mesenchymal stem cell: Stem cell therapy for type 1diabetes in Proc Rom Acad (2008) 1: 59 -70.

8. Abraham EJ, Leech C., Lin JC, Zulewski H and Habener JF: Insulinotropic hormone glucagon-like peptide-1 differentiation of human pancreatic isletderived progenitor cells into insulin producing cells in Endocrinology (2002) 143: 3152- 3161.

9. Stagg J and Galipeau J: Mechanisms of immune modulation by mesenchymal stromal cells and clinical translation in Curr Mol Med (2013) 13: 856- 867.

10. Phinney D and Prockop D: Concise review: Mesenchymal stem/Multipotent stromal cells: The state of transdifferentiation and modes of tissue repair - Current views in Stem Cells (2007) 25: $2896-2902$.

11. Cao M, Pan Q, Dong H, Yuan X, Li Y, Sun Z, Dong $\mathrm{X}$ and Wang $\mathrm{H}$ : Adipose-derived mesenchymal 
stem cells improve glucose homeostasis in highfat diet-induced obese mice in Stem Cell Research and Therapy (2015) 6: $208-220$.

12. Hass R, Kasper C, Böhm S and Jacobs R: Different populations and sources of human mesenchymal stem cells (MSC): A comparison of adult and neonatal tissue-derived MSC in Cell Communication and Signaling (2011) 9: 12- 26.

13. Oh SH, Muzzonigro T., Bae SH, LaPlante JM, Hatch HM and Petersen BE: Adult bone marrow derived cells trans-differentiating into insulinproducing cells for the treatment of type I diabetes in Lab Invest (2004) 84: 607- 617.

14. Li YY, Liu HH, Chen HL and Li YP: Adiposederived mesenchymal stem cells ameliorate STZinduced pancreas damage in type 1 diabetes in Biomed Mater Eng (2012) 22(1- 3):97- 103.

15. Huang SP, Hsu CC, Chang SC, Wang CH, Deng SC, Dai NT, Chen TM, Chan JY, Chen SG and Huang SM: Adipose derived stem cells seeded on a cellular dermal matrix grafts enhance wound healing in a murine model of a full-thickness defect in Ann Plast Surg (2012) 69: 656 -662.

16. Rochefort GY, Vaudin P, Bonnet N, Pages JC, Domenech J, Charbord P and Eder V: Influence of hypoxia on the domiciliation of Mesenchymal Stem Cells after infusion into rats: possibilities of targeting pulmonary artery remodelling via cells therapies? in Respiratory Research (2005) 6: 125- 137.

17. Alhadlaq A and Mao JJ: Mesencymal stem cells isolation and therapeutics in Stem cells Dev. (2004) 13: 436- 448.

18. Ode A, Kopf J, Kurtz A, Schmidt-Bleek K, Schrade P, Kolar P, Buttgereit F, Lehmann K, Hutmacher DW, Duda GN and Kasper G: CD73 and CD29 concurrently mediate the mechanically induced decrease of migratory capacity of mesenchymal stromal cells in Eur Cell Mater. (2011) 6: 26- 42.

19. Louis KS and Siegel AC: Cell viability analysis using trypan blue: manual and automated methods in Methods Mol. Biol. (2011) 740: 7- 12.
20. Kyriakou C, Rabin N, Pizzey A, Nathwani A and Yong K: Factors that influence short-term homing of human bone marrow-derived mesenchymal stem cells in a xenogeneic animal model in Haematologica (2008) 93: 1457- 1465.

21. Bhansali S, Kumar V, Saikia U, Medhi B, Jha V, Bhansali A and Dutta P: Effect of mesenchymal stem cells transplantation on glycaemic profile and their localization in streptozotocin induced diabetic Wistar rats in Indian J Med Res (2015) 142: $63-71$

22. Abdel Aziz M, Wassef1 M, Ahmed H, Rashed L, Mahfouz S, Aly M, Hussein R and Abdelaziz M: The role of bone marrow derived-mesenchymal stem cells in attenuation of kidney function in rats with diabetic nephropathy in Diabetology \& Metabolic Syndrome (2014) 6:34- 44.

23. Lin G, Wang G, Banie L, Ning H, Shindel AW, Fandel TM, Lue TF and Lin C: Treatment of Stress Urinary Incontinence with Adipose TissueDerived Stem Cells in Cytotherapy (2010) 12(1): $88-95$.

24. Wan J, Xia L, Liang W, Liu Y, and Cai Q: Transplantation of Bone Marrow-Derived Mesenchymal Stem Cells Promotes Delayed Wound Healing in Diabetic Rats in Journal of Diabetes Research (2013) 2013: 1- 11.

25. Cesaretti ML, Ginoza $M$, Ribeiro $A B$ and Kohlmann O Jr: Systemic hemodynamic and left ventricular function of diabetic- induced hypertensive rats in Arq Bras Endocrinol Metabol (2010) 54: 842- 851.

26. Kiernan J: Histological and histochemical methods: theory and practice. $3^{\text {rd }}$ ed., Arnold publisher. London, New York \& New Delhi. (2001) pp: $111-162$.

27. Bancroft $\mathbf{J}$ and Gamble $\mathbf{M}$ Theory and Practice of Histological Techniques. $7^{\text {th }}$ ed., staining methods, Churchill Livingstone, Edinburgh, London, Madrid, Melbourne, New York and Tokyo. (2008) pp: $263-325$.

28. Emsley R, Dunn G and White IR: Mediation and moderation of treatment effects in randomised 
controlled trials of complex interventions in Stat Methods Med Res (2010) 19: 237- 270.

29. Ismail ZM, Kamel AM, Yacoub MF and Aboulkhair AG: The effect of in vivo mobilization of bone marrow stem cells on the pancreas of diabetic albino rats (a histological and immunohistochemical study) in Int J Stem Cells (2013) 6 (1):1- 11.

30. Abunasef SK, Amin HA and Abdel-Hamid GA: A histological and immunohistochemical study of beta cells in streptozotocin diabetic rats treated with caffeine in Folia histochem cytobiol. (2014) 52(1): 42- 50 .

31. Sheweita S, Mashaly S, Newairy A, Abdou H and Eweda S: Changes in Oxidative Stress and Antioxidant Enzyme Activities in StreptozotocinInduced Diabetes Mellitus in Rats: Role of Alhagi maurorum Extracts in Oxidative Medicine and Cellular Longevity (2016) 2016: 1 -8.

32. Lenzen S: The mechanisms of alloxan- and streptozotocin-induced diabetes in Diabetologia (2008) 51:216- 226.

33. John A and Ira D: The insulin-acinar relationship. The pancreas: Biology, Pathobiology, and Disease. Raven Press, Ltd., New York. $2^{\text {nd }}$ ed., chapter 41. (1993) pp: 789- 802.

34. Fiorina P, Jurewicz M, Augello A, Vergani A, Dada S, La Rosa S, Selig M, Godwin J, Law K, Placidi C, Smith RN, Capella C, Rodig S, Adra CN, Atkinson $\mathrm{M}$, Sayegh MH and Abdi R: Immunomodulatory function of bone marrow-derived mesenchymal stem cells in experimental autoimmune type 1 diabetes in Journal of Immunology (2009) 183(2): 993- 1004.

35. Meirelles LS, Fontes AM, Covas DT and Caplan AI: Mechanisms involved in the therapeutic properties of mesenchymal stem cells in Cytokine Growth Factor Rev (2009) 20: 419- 427.

36. Volarevic V, Al-Qahtani A, Arsenijevic N, Pajovic $\mathrm{S}$ and Lukic ML: Interleukin-1receptor antagonist (IL-1Ra) and IL-1Ra producing mesenchymal stem cells as modulators of diabetogenesis in Autoimmunity (2010) 43: 255- 263.

37. Tögel F, Weiss $\mathrm{K}$, Yang $\mathrm{Y}, \mathrm{Hu} \mathrm{Z}$, Zhang $\mathrm{P}$ and Westenfelder C: Vasculotropic, paracrine actions of infused mesenchymal stem cells are important to the recovery from acute kidney injury in Am J Physiol Renal Physiol (2007) 292(5):1626- 1635.

38. Milanesi A, Lee JW, Li Z, Sacco S, Villani V, Cervantes V, Perin L, Yu JS: Beta-Cell regeneration mediated by human bone marrow mesenchymal stem cells in PLoS ONE (2012) 7(8): e42177.

39. Pileggi A: Mesenchymal stem cells for the treatment of diabetes in Diabetes (2012) 61: 1355- 1356 .

40. Si Y, Zhao Y, Hao H, Liu J, Guo Y, Mu Y, Shen J, Cheng Y, Fu X and Han W: Infusion of mesenchymal stem cells ameliorates hyperglycemia in type 2 diabetic rats: identification of a novel role in improving insulin sensitivity in Diabetes (2012) 61:1616- 1625 .

41. Ianus A, Holz GG, Theise ND and Hussain MA: In vivo derivation of glucose-competent pancreatic endocrine cells from bone marrow without evidence of cell fusion in Journal of Clinical Investigation (2003) 111(6):843- 850.

42. Zhang $\mathrm{Y}$ and Wang $\mathrm{W}$ Effects of Bone Marrow Mesenchymal Stem Cell Transplantation on LightDamaged Retina. Invest in Ophthalmol. Vis. Sci (2010) 51(7): 3742- 3748.

43. Lechner A, Yang YG, Blacken RA, Wang L and Habener JF: No evidence for significant transdifferentiation of bone marrow into pancreatic beta-cells in vivo in Diabetes (2004) 53(3):616 -623.

44. Zhang HT, Liu ZL, Yao XQ, Yang ZJ and Xu RX: Neural differentiation ability of mesenchymal stromal cells from bone marrow and adipose tissue: a comparative study in Cytotherapy (2012) 14:1203- 1214.

45. Ock SA, Subbarao RB, Lee YM, Lee JH, Jeon RH, Lee SL, Park JK, Hwang SC and Rho GJ: Comparison of Immunomodulation Properties of Porcine Mesenchymal Stromal/Stem Cells Derived from the Bone Marrow, Adipose Tissue, and Dermal Skin Tissue in Stem Cells Int. (2016) 2016: 9581350 .

46. Gouveia de Andrade AV, Bertolino G, Riewaldt J, Bieback K, Karbanová J, Odendahl M, Bornhäuser M, Schmitz M, Corbeil D and Tonn T: Extracellular vesicles secreted by bone marrowand adipose tissue-derived mesenchymal stromal 
cells fail to suppress lymphocyte proliferation in Stem Cells Dev. (2015) 24(11):1374- 1376.

47. Ribeiro A, Laranjeira P, Mendes S, Velada I, Leite C, Andrade P, Santos F, Henriques A, Grãos M, Cardoso CM, Martinho A, Pais M, de Silva CL, Cabral J, Trindade H, and Paiva A: Mesenchymal stem cells from umbilical cord matrix, adipose tissue and bone marrow exhibit different capability to suppress peripheral blood B, natural killer and $\mathrm{T}$ cells in Stem Cell Res Ther. (2013) 4(5): 125- 141.

48. Gutiérrez-Fernández M, Rodríguez-Frutos B, Ramos-Cejudo J, Teresa M, Fuentes B, Cerdán $\mathrm{S}$ and Díez-Tejedor E: Effects of intravenous administration of allogenic bone marrow- and adipose tissue-derived mesenchymal stem cells on functional recovery and brain repair markers in experimental ischemic stroke in Stem Cell Research snd Therapy (2013) 4(1):11 -21.

49. Gutiérrez-Fernández M, Rodríguez-Frutos B, Ramos-Cejudo J, Otero-Ortega L, Fuentes B, Vallejo-Cremades M, Sanz-Cuesta B and DíezTejedor E: Comparison between xenogeneic and allogeneic adipose mesenchymal stem cells in the treatment of acute cerebral infarct: proof of concept in rats in Journal of Translational Medicine (2015) 13: $46-55$

50. Dong QY, Chen L, Gao GQ, Wang L, Song J, Chen B, Xu YX and Sun L: Allogeneic diabetic mesenchymal stem cells transplantation in streptozotocin-induced diabetic rat in Clin Invest Med. (2008) 31(6):E328- 337. 
الملخص العربى



عبير إبراهيم عمر والشيماء جمال أبو الخير

قسم الهستولوجيا ـ كلية الطب ـ جامعة القاهرة ـ القاهرة ـ مصر

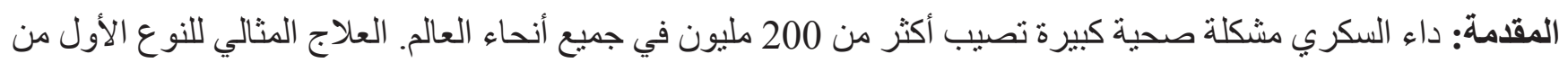

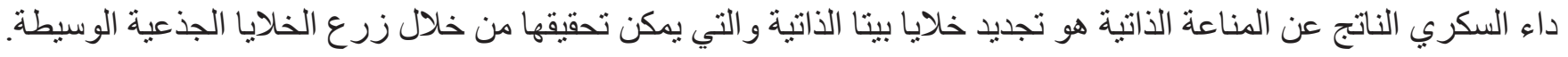

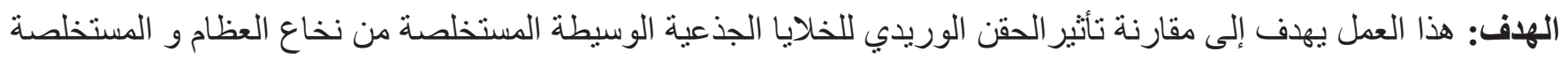

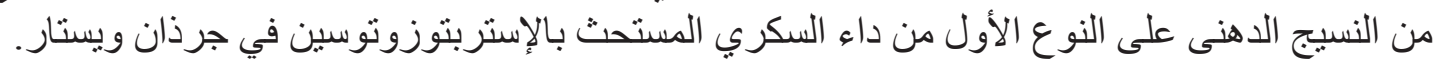

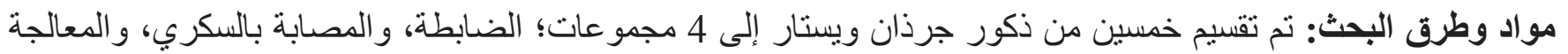

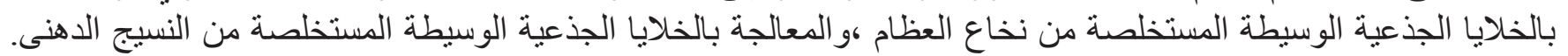

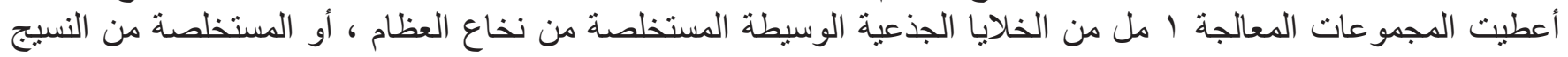

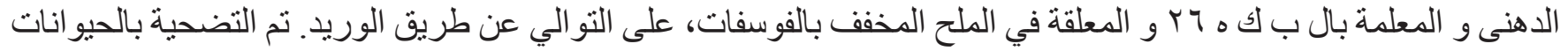

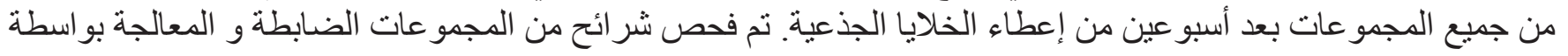

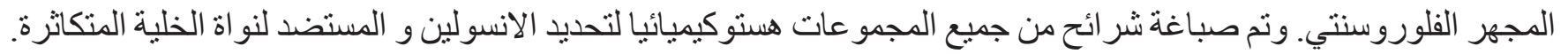

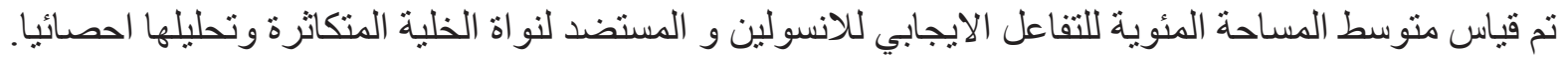

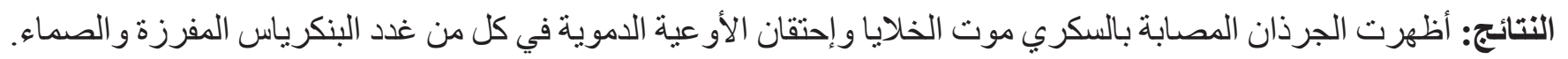

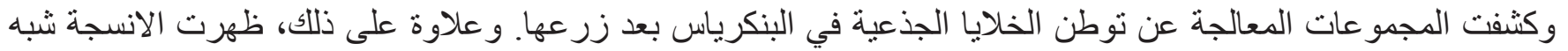

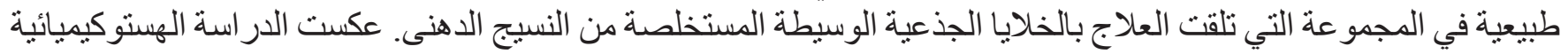

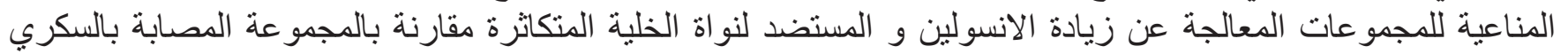

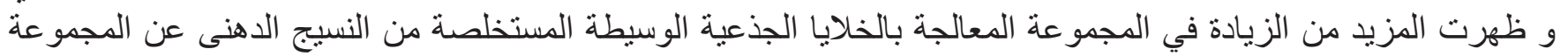

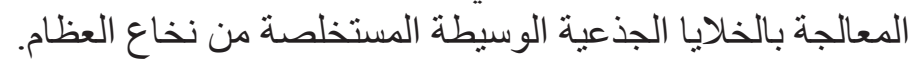

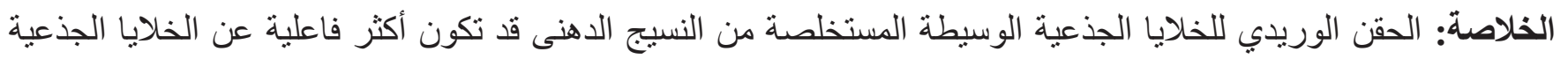

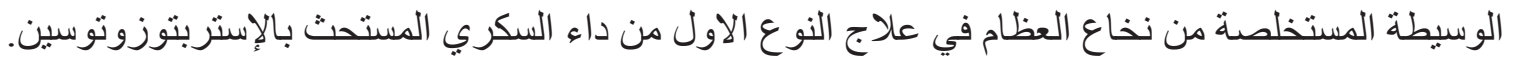

